\title{
NEW LITHOSTRATIGRAPHIC AND STRUCTURAL ASPECTS IN THE SOUTHERN PART OF THE BIHOR MASSIF (APUSENI MOUNTAINS)
}

\author{
I. BALINTONI ${ }^{1}$, A. PUSTTE ${ }^{1}$
}

\begin{abstract}
The Muncel Series (lonescu, 1962), from the Bihor massif can be included in the Permian Pă iușeni Lithogroup, because it consists predominantly from weak metamorphosed granites and porphyres. In this idea, the Highis Nappe correlates with the Muncel Nappe and does not with the Poiana Nappe. Consequently, the down to up succession of the Biharia Nappe System becomes: the Gârda Nappe; The Ravicești scale; the Poiana Nappe; the Piatra Gră itoare scale; the Biharia nappe; the Highiș-Muncel Nappe; the Baia de Arieș Nappe.
\end{abstract}

KEYWORDS: Muncel Nappe, Muncel Series, Highiș Nappe, Pă iușeni Lithogroup.

\section{INTRODUCTION}

According to Bordea et al., (1988), the Biharia massif is formed from the Moma - Arieșeni, Poiana, Biharia with its lower Piatra Gră itoare scale, and Muncel nappes, which have among their components the following metamorphosed lithostratigraphic units: the Moma - Arieșeni Nappe, the Lower Carboniferous Ariesseni Series greenschists; the Poiana Nappe, the Upper Carboniferous Poiana Series; the Biharia Nappe, the Devonian - Lower Carboniferous Pă iușeni series and the Vendian - Lower Cambrian Biharia Series; the Muncel Nappe, the Lower Cambrian - Ordovician (?) Muncel Series.

Balintoni (1994), included the Arieseni Nappe in the Biharia Nappe System and put together the Poiana Nappe, Piatra Gră itoare Scale and Biharia Nappe into the Alpine Biharia Nappe, separating them each other by pre-Alpine thrusts. This author also considered the Muncel Nappe as a western prolongation of the Baia de Aries Nappe. Lithostratigraphically, Balintoni (1994), divided the Muncel Series in a lower part compared with the Biharia Series (the Necsesti Formation according to Bordea et al., 1988), and an upper part paralleled with the Baia de Arieș Series. Between them has been traced a pre-Alpine tectonic plan.

Balintoni (1997), brought together the Arieșeni, Poiana and Pă iușeni Series as the Pă iușeni Lithogroup, metamorphosed during the Variscan orogeny.

In 1998, the same author, renounced to the pre-Alpine thrust and separated in the Bihor Massif the Alpine Arieșeni Nappe, Highiș-Poiana Nappe, Piatra Gră itoare Scale, Biharia Nappe, Muncel Scale and Baia de Arieș Nappe. He kept the lithostratigraphy unchanged, but hypothesized a Lower Permian age for the Pă iușeni Lithogroup.

\footnotetext{
1 "Babes-Bolyai" University, 1 Kogalniceanu str, 3400 Cluj Napoca, Romania
} 
Pană (1998), proved by zircon U/Pb isotopic dating the Permian age of the Pă iușeni Lithogroup, and the Uppermost Cambrian - Lowermost Ordovician age of the Biharia Lithogroup. Balintoni et al., (2002), found that the red Permian deposits from the Arieseni Nappe belong to the Moma Nappe and the Arieșeni Lithozone is structurally situated in the same context as the Poiana Lithozone. Consequently, the Ariesseni Nappe disappears, and the Ariesseni Lithozone becomes a component part of the Poiana Nappe. Thus the Poiana Nappe surface is increasing and its content enriches. Further on this paper refers to the Muncel Nappe according to Bordea et al., (1988), or to the Muncel ScaWle and the Baia de Arieș Nappe according to Balintoni (1998).

\section{The Muncel Nappe, concept evolution}

The Muncel Nappe appears on a cross section published by Rozlozsnik (1935), named "mylonit decke". Giușcă (1937), perfectly drawn the Muncel Nappe, separating "schistes chloriteux à porphiroblastes d'albite" or "le cristallin de Biharea" beneath a "complexe de phyllites et épigranites". These two lithologies formed the "Biharia Series" and the "Muncelu Series" according to lonescu, (1962). But the name "Muncelu Series" was already used by Bleahu and Dimitrescu (1957). lanovici et al., (1976), and Bordea et al., (1988), included the Biharia Series in the Muncel Series, as the Necșești Formation. Balintoni (1985), shown that the Muncel (-Lupșa) Series differentiated by Dimitrescu et al., (1974, 1977), along the Aries Valley, partially belongs to Biharia Lithogroup and partially to Baia de Aries Lithogroup. In 1994, Balintoni applied the same rule for the Bihor Massif. But if the Necssești Formation truly belongs to Biharia Lithogroup as already saw Giuscă (1937), the rest of the Muncel Series does not represent the prolongation of the Baia de Arieș Lithogroup or Nappe.

\section{The Muncel Series lithology and metamorphism}

The Muncel Series lithology was established by Giușcă (1937), Ionescu, (1962), and Bordea et al., (1988). It is important to say that the Muncel Series lithology in the Bihor massif differs of the Muncel (-Lupșa) lithology along the Arieș Valley. Giușcă (1937), spoke about phyllites, epigranites and porphyroides. According to lonescu (1962), it consists from sericite, sericite-chlorite and graphitesericite phyllites, from cataclastic gneissic granites, from porphyroids, and from gray quartzites. The mylonitic aspect of the granites is also emphasized by Bordea et al., (1988), and we remember the "mylonite decke" figured by Rozlozsnik (1935). Several features can be stressed: (a) the metagranitoids - metaporphyres obvious association; (b) the mesoscopic identity between the Muncel Series metaporphyres and the red Permian quartz-porphyries or the metaporphyries of the Pă iușeni Lithogroup from the northern part o the Highiș massif; (c) the outcrop scale transition between weak deformed porphyres and porphyroclastic phyllites.

The metamorphism of these rocks has been studied by lonescu (1962). He described as metamorphic minerals, chlorite, sericite and albite. An important characteristic of the granites and porphyreis is the plenty of relic magmatic 
minerals: plagioclase, orthose, biotite, muscovite. Biotite is partially chloritized and the plagioclase sericitized. The penetrative foliation is coarse one and the metamorphic recrystallisation of the granite minerals incipient. The cataclastic deformation predominates and the metamorphic alterations are depending on the crushing degree. The rocks rather appear as cataclasites and mylonites than metamorphics. This low grade metamorphism, dependent on the deformation intensity is characteristic for the Pă iușeni Lithogroup rocks and it was well illustrated by Pană (1998), in the Highiș massif.

\section{Discussions}

Because in the southern part of the Biharia massif the Muncel Series overlies Biharia Lithogroup rocks and its lithology and metamorphic degree are not compatible with those of the Baia de Arieș Lithogroup, we consider it as a part of the Pă iușeni Lithogroup.

As we suggested, it is rather comparable with the Highis Lithozone, than with the Pă iușeni Lithogroup fragments located in the lower tectonic units. A north-south arrangement of the Pă iușeni Lithogroup components shows in this way: Pă iușeni - Poiana, Pă iușeni - Piatra Gră ioare, Pă iușeni - Biharia, Pă iușeni - Muncel and Pă iușeni - Highiș Lithozones. The Pă iușeni - Poiana, Pă iușeni Piatra Gră ioare and Pă iușeni - Biharia lithozones are especially dominated by metaconglomerates and they contain few metamagmatites. Instead, in the Pă iușeni - Muncel and Pă iușeni - Highiș lithozones abound the metamagmatites. This aspect suggests a closer initial location between the Pă iușeni - Highiș and the Pă iușeni - Muncel lithozones than between the Pă iușeni - Highiș and any other more northern lithozone.

The inference has structural results: a correlation between Highis and Muncel Nappes is much more probably than the current correlation between the Highis and Poiana Nappes. If this hypothesis is correct, then the initial position of the Biharia Nappe has been northerly of the Highiș Nappe, what reduces the tectonic transport within the Biharia Nappe System.

In a synthetic manner, the main hypotheses proposed in this paper are: (a) the correlation between the Highis and the Muncel Nappes; (b) the inclusion of the Muncel Series into the Pă iușeni Lithogroup as the Muncel Lithozone. Therefore, the Biharia Nappe System consists down to up from: the Gârda Nappe, the Ravicești scale, The Poiana Nappe, the Piatra Gră itoare scale, the Biharia Nappe, the Highis - Muncel Nappe, the Baia de Arieș Nappe.

Excepting the Gârda Nappe and Ravicești scale, the Upper Paleozoic and Mesozoic of the other tectonic units undergone an Alpine dynamo-thermal metamorphism during the nappe emplacement.

\section{Conclusions}

1. The Muncel Nappe from the Bihor massif, represents the prolongation of the Highiș Nappe. It consists from Biharia and Pă iușeni Lithogroups rocks. 
2. The Muncel granites and porphyries can be the oldest magmatic rocks of the Permian Pă iușeni Lithogroup.

3. The uppermost graphite quartzites from the previous Muncel Series lonescu, (1962), is possible to belong to the Baia de Aries Lithogroup and Nappe. around them.

4. It is not clear why the Muncel granites have not a hornfelse aureole

Acknowledgments: This paper was supported by the grant 46174/27.11.1997, theme 16, with World Bank.

\section{REFERENCES}

Balintoni, I., (1985), Corrélation des unités lithostratigraphiques et tectoniques longeant le ruisseau d'Arieș entre la vallée de lara et le mont Gă ina, (Monts Apuseni), D. S. Inst. Geol.Geofiz., LXIX/5 (1982), 5-15, București.

Balintoni, I., (1994), Structure of the Apuseni Mountains, ALCAPA II, Field Guide-Book, Rom. Jour. Tect. Reg. Geol., 75. Suppl. 2, 51 - 58, București.

Balintoni, I., (1997), Geotectonica terenurilor metamorfice din România, Ed. Carpatica, 176 p., Cluj Napoca.

Balintoni, I., Ghergari, L., Bă but , T., (2002), The Arieșeni Nappe, or the Moma and Poiana Nappes?, Stud. Univ. "Babeș-Bolyai" in press.

Balintoni, I., Stan, R., (1998), Codru Nappe System and Biharia Nappe System: comparison. An. Inst. Geol. Rom., 70, 141-147, București.

Bleahu, M., Dimitrescu, R., (1957), Stratigrafia și tectonica Munt ilor Apuseni (cu privire specială asupra cristalinului și Mezozoicului), Anal. Rom.-Sov. (Geol. Geogr.), Seria a 2-a, 2, 29-42.

Bordea, S., Dimitrescu, R., Mantea, G., Stefan, A., Bordea, J., Bleahu, M., Costea, C., 1988, Harta Geologică a României, sc. 1:50.000, foaia Biharia, Inst. Geol., București.

Dimitrescu, R., Bleahu, M., Lupu, M., (1977), Harta Geologică a României, sc. 1:50.000, foaia Avram lancu, Inst. Geol., București.

Dimitrescu, R., Bordea, S., Bordea, J., (1974), Harta Geologică a României, sc. 1:50.000, foaia Câmpeni, Inst. Geol., București.

Giuscă, D., (1937), Les phénomènes de metamorphisme hidrotermal des roches paléozoïques des Monts Bihor, Bul. Lab. Mineral. Univ. Buc., II, 51-59.

lanovici, V., Borcos, M., Bleahu, M., Patrulius, D., Lupu, M., Dimitrescu, R., Savu, H., (1976), Geologia Munț ilor Apuseni, Ed. Acad. Rom, 631 pp, București.

Ionescu, C., (1962), Cercetă ri geologice și petrografice în cristalinul Munț ilor Bihor (Biharia), Anu. Com. Geol., XXXII, 167-209, București.

Pană , D., (1998), Tectonics of the Carpathian-Pannonian region. PhD Thesis, 356 p., Univ Alberta, Edmonton, Canada.

Rozlozsnik (1935), Neue Beiträge zur Kenntnis der metamorphen Gesteine der Umgebung des Nagybihar, Föld. Közl., LXV, 81-90, Budapest. 


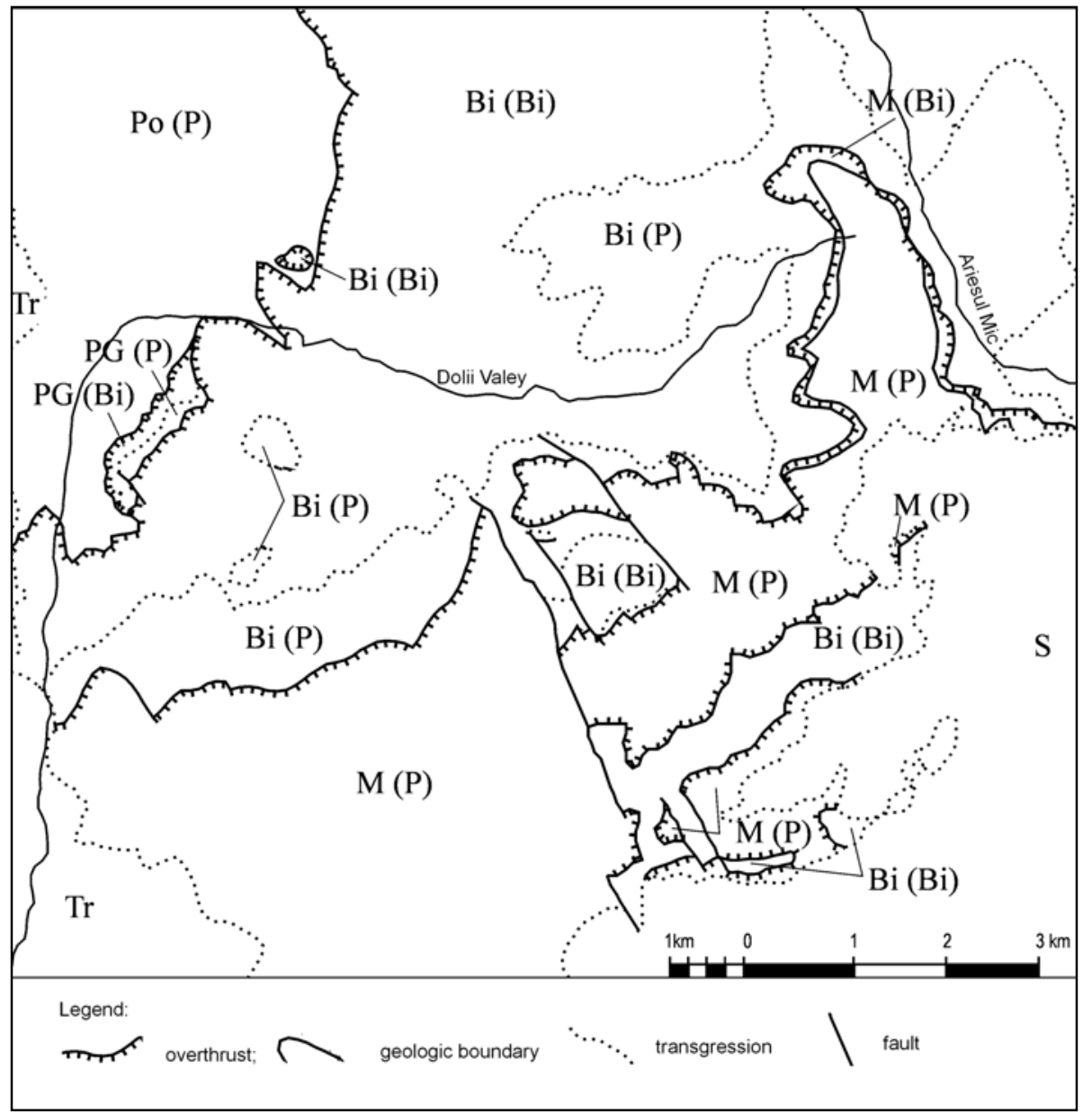

Fig. 1. Tectonics and lithostratigraphy of southern Bihor, Apuseni Mountains.

Legend: Po, Poiana Nappe; PG, Piatra Graitoare Scale; Bi, Biharia Nappe; M, Highiș-Muncel Nappe; (Bi), Biharia Lithogroup, (P), Paiuseni Lithogroup; S, Senonian sedimentary; Tr, Tertiary sedimentary. 


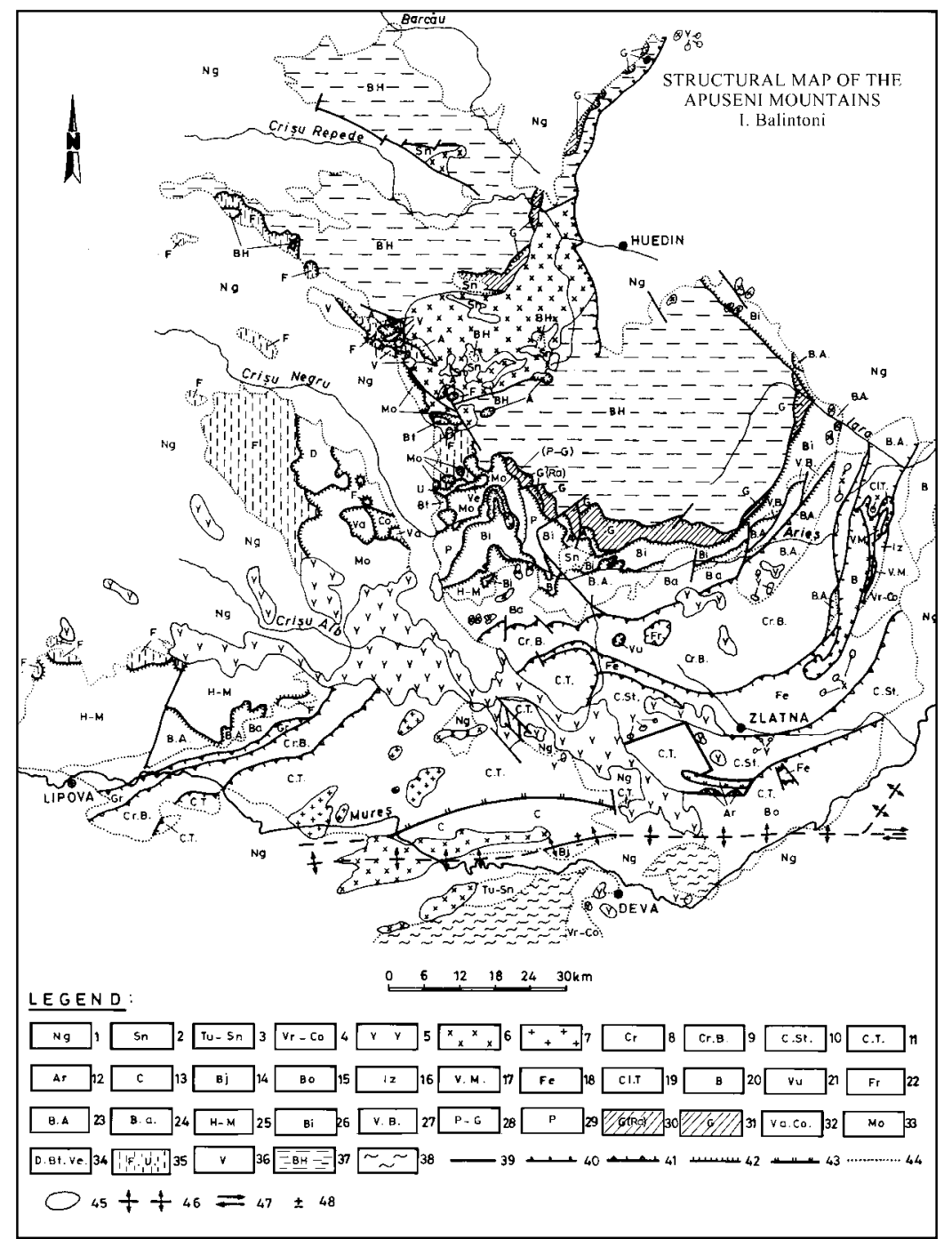

Fig. 2 Structural Map of the Apuseni Mountains

1, Neogene; 2, Senonian; 3, Turonian-Senonian; 4, Vraconian - Coniacian; 5, Neogene extensional magmatites; 6, banatitic subduction related (Upper Cretaceous) magmatites; 7, Jurassic granite. Laramian Transylvanides: 8, Grosi unit; 9, Cris-Bucium nappe; 10, Curechiu-Stanija nappe;

Austrian units components of the Mures Laramian nappe: 11, Capâlnas-Techereu nappe; 12, Ardeu unit; 13, Cabesti unit; 14 Bejan unit; 15, Upper Cretaceous Bozes beds.

Austrian units components of the Metaliferous mountains Laramian nappe: 16, Izvoarele nappe; 17, Valea Muntelui nappe; 18, Austrian units components of the Metaliferous mountains Laramian nappe: 16, Izvoarele nappe; 17, Valea Muntelu
Fenes nappe; 19, Coltu Trascaului nappe; 20, Bedeleu nappe. Other Laramian units: 21, Vulcan nappe; 22, Frasin nappe.

Apusenides: Biharia Nappe System: 23, Baia de Aries nappe; 24, Upper Cretaceous cover of Baia de Aries nappe; 25, HighişMuncel Nappe 26. Biharia nappe; 27, Vulturese-Belioara series; 28, Piatra Graitoare scale; 29, Poiana nappe; 30, Raviceşti scale; 31, Gârda nappe;

Codru Nappe System: 32, Vascau-Colesti nappe (or Colesti and Vascau); 33, Moma nappe; 34, Dieva-Batrânescu-Vetre nappe; 35 , Finis (- Ferice-Umat) nappe; 36, Valani nappe.

37, Bihor Unit;

38, South Carpathians Crystalline;

39, fault; 40, inverse fault; 41, Laramian overthrust; 42, Pre-Gosau overthrust; $\mathbf{4 3}$, Austrian overthrust 44, transgression; 45, magmatic rocks boundary; $\mathbf{4 6}$, craton boundary shear zone; $\mathbf{4 7}$, wrench fault movement sense; $\mathbf{4 8}$, fault compartments. 